\title{
Early description of synchronous double spinal vascular malformations by Łucja Frey in 1928
}

\author{
Philippe Gailloud, MD \\ Division of Interventional Neuroradiology, The Johns Hopkins Hospital, Baltimore, Maryland
}

The Polish neurologist Łucja Frey (1889-1942) is principally remembered for her description of the auriculotemporal nerve (or Frey's) syndrome. She also reported a complex case of spinal cord vascular malformation in 1928, which included one of the earliest accurate anatomopathological depictions of a spinal arteriovenous malformation as well as the first known observation of double synchronous spinal cord vascular malformation.

An abbreviated translation of Frey's report is followed by a discussion of the place occupied by her contribution in the development of our current understanding of spinovascular disorders.

http://thejns.org/doi/abs/10.3171/2016.1.SPINE151200

KEY WORDS multiple spinal vascular malformations; spinal arteriovenous fistula; spinal arteriovenous malformation; history

七 UCJA Frey (1889-1942) is principally remembered for her description of the auriculotemporal nerve syndrome (or Frey's syndrome). ${ }^{6}$ She also described a complex case of spinal cord vascular malformation, both in Polish (1926) ${ }^{17}$ and in French (1928). ${ }^{16}$ A modern assessment of this neglected contribution suggests that, besides providing one of the earliest accurate anatomopathological depictions of a spinal arteriovenous malformation (AVM), Frey likely reported the first known observation of double synchronous spinal vascular malformations.

An abbreviated translation of Frey's report is followed by a discussion of the place occupied by her contribution in the development of our current understanding of spinovascular disorders.

\section{Łucja Frey's Contribution}

What follows is my translation of Frey's report. ${ }^{16}$ The original bibliography has been incorporated in the general bibliography.

\section{Anatomo-Clinical Study of a Case of Cirsoid Aneurysm of the Spinal Cord}

J. T., a 52-year-old mason, was admitted for paraplegia on November 3, 1924. During the previous 9 years, the patient had felt tingling, first in his feet, then progressively ascending to reach the epigastric region about 2 years ago. He was otherwise in good health, working until October 22,1924 , when lower-extremity weakness developed suddenly.

\section{Status at Admission}

There was almost complete paralysis of the inferior limbs, particularly on the right. The touch, prick, heat and cold sensibilities were severely impaired in both lower limbs.

Soon after admission, an extensive decubitus ulcer formed in the sacral region. The patient died on December 10, 1924, from bronchopneumonia.

\section{Necropsy}

Once the dura was opened, the posterior aspect of the cord appeared to be entirely covered by markedly thickened and sinuous vessels. These vascular changes were particularly noticeable in the lumbar region, slightly less pronounced in the inferior cervical and superior dorsal regions; the superior cervical and mid-dorsal regions were almost normal. On a cut passing through the seventh cervical segment, vessels were seen penetrating through the anterior spinal fissure into the nervous substance itself, almost occupying the anterior two-thirds of the slice sur-

ABBREVIATIONS AVF = arteriovenous fistula; $A V M=$ arteriovenous malformation; $D A V F=$ dural AVF

SUBMITTED October 7, 2015. ACCEPTED January 21, 2016

INCLUDE WHEN CITING Published online March 25, 2016; DOI: 10.3171/2016.1.SPINE151200. 
face. Enlarged vessels of various calibers were visible to the naked eye in the medullary substance. On lower sections, the extent of the surface occupied by vessels sharply decreased and, at the T-2 level, there was only one sac-like distended vessel. At the T-4 level, the cord presented an almost normal quality. But, at the T8-10 level, one found again a dilated, sac-shaped vessel, which, penetrating through the anterior fissure, almost reached the posterior surface of the cord. No macroscopic alterations were noted below T-10.

Within the spinal cord itself, extreme blood vessel changes started at the seventh cervical level. On the ventral aspect, a large number of vessels covered a considerable portion of the slice, entirely occupying the anterior horn on one side, reaching the lateral edge of the cord (Fig. 1A). A section through the fourth dorsal segment already showed a normal appearance. At the T- 8 level, one found again, as mentioned in the macroscopic description, a large and dilated vessel along the midline, almost reaching the posterior aspect of the cord (Fig. 1B). It was likely here a vein, as an elastic membrane was not detected using the Weigert method (Fig. 1C).

Vascular anomalies dominate our case's anatomopathological picture. Two different forms can be distinguished: 1) the multiplication of vessels of various calibers within the nervous substance of the cord and 2) the multiplication and hypertrophy of pial vessels.

Which type of vascular disorder is our case showing?
The pathological alterations consisted in the hypertrophy of preformed vessels and dilation of their lumina. The lesion thus corresponds to a cirsoid aneurysm.

In our case, the lesion must be very old, since clinical symptoms had been noted for 9 years already, and the pathological process was likely present for a much longer period.

One thus has to admit that a congenital malformation of the spinal vascular system constitutes the essential cause of the hypertrophy of the vessels. Since an excessive number of preformed vessels were present, this malformation must have existed since the earliest stages of development. The vascular malformation, which developed next to a hypoplasia of the nervous substance at the seventh cervical level, probably dates from that early period.

Angiomas presenting as focal tumors ${ }^{4,18,20,23,34,52,55}$ do not belong to the same category as our observation; neither does the case of Hebold ${ }^{24}$ with several aneurysms of the spinal cord small vessels. One must also eliminate cases consisting of spinal varices, ${ }^{27,28,32,54}$ as well as surgical cases not confirmed by autopsy. ${ }^{12,15,22}$ The case of Brasch $^{5}$ differs by the fact that the vessels compromised the nervous substance by compression only. Two cases are almost identical to ours in regard to the anatomopathological picture. Meyer and Kohler ${ }^{38}$ observed a case initially simulating a syringomyelia. The autopsy showed a tumor produced by the loops of a tortuous vessel that penetrated in the depth of the cord at the level of L-2. The
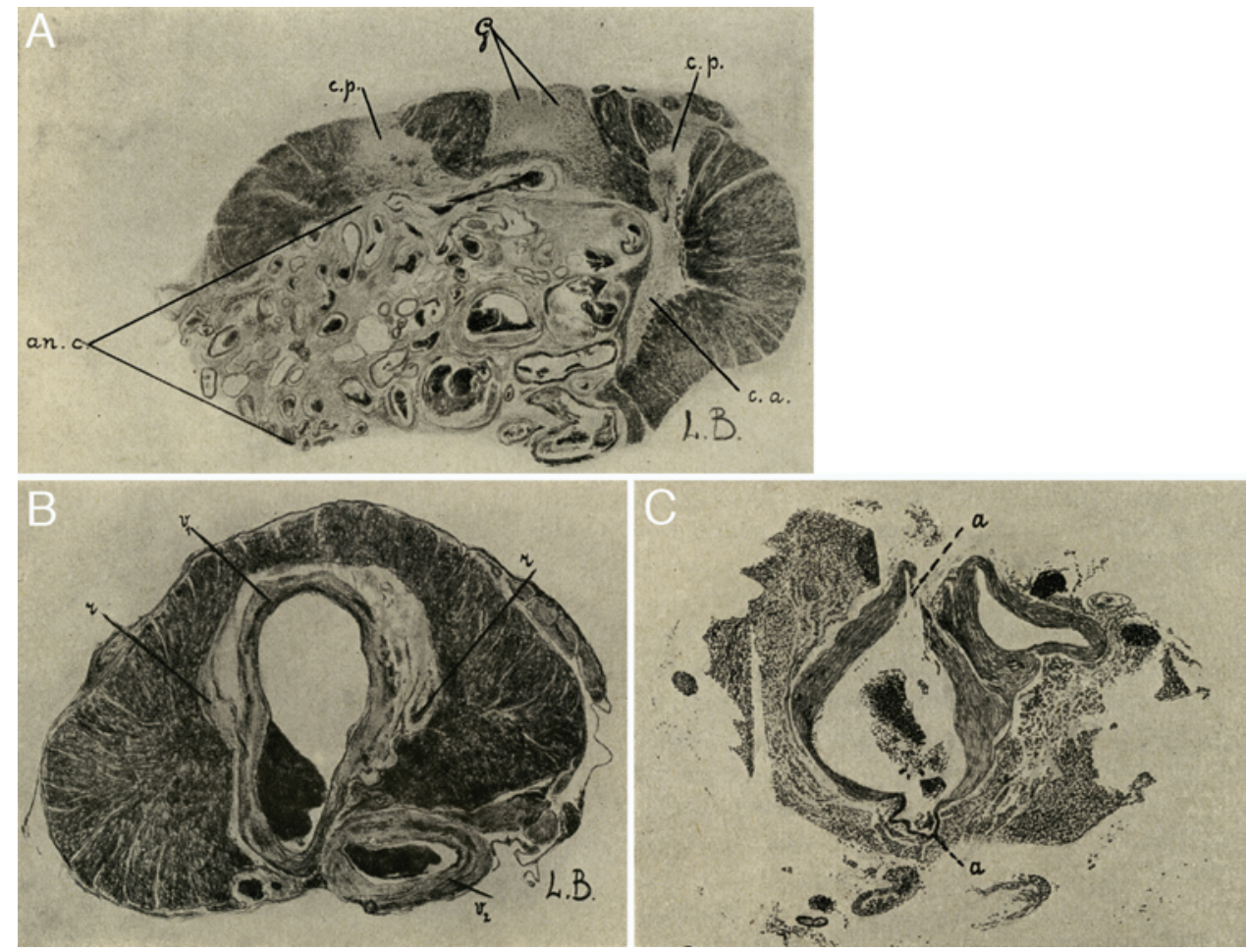

FIG. 1. Frey's Figs. 1-3, with original legend key, reproduced from the Annales d'Anatomie Pathologique in 1928. A: C-7, WeigertPal coloration (reproduction of Frey's Fig. 1). an. c. = cirsoid aneurysm; c.a. = residual anterior horn; c.p. = posterior horns, which does not exist on the other side; $G=$ degenerated tracts of Goll. B: T-8, Weigert-Pal coloration (reproduction of Frey's Fig. 2). $r=$ remainder of the gray substance; $V_{1}=$ markedly dilated vessel with altered walls, which penetrates through the anterior fissure into the cord; $V_{2}$, = pial vessel. C: T-10, H \& E coloration (reproduction of Frey's Fig. 3). $a$ = intramural aneurysms in a dilated vessel, located in the center of the cord. Public domain. Figure is available in color online only. 
microscopic exam revealed arteries as well as veins. There was a multiplication of vessels within the spinal nervous substance. The case of Raymond and Cestan ${ }^{48}$ differs from ours only by the preponderant participation of veins in the pathological process.

\section{Łucja Frey}

Łucja Frey was born in 1889 in the city of Lwów. She initially trained in mathematics, qualifying as a secondary school teacher in $1913 .{ }^{40}$ She started to study medicine relatively late, in 1917, at the age of 28 years. After a brief interruption, possibly related to the birth of her son, she resumed her medical education in Warsaw, where she became senior assistant to Kazimierz Orzechowski (1878-1942), the first director of the Department of Nervous Diseases of the University of Warsaw ${ }^{13}$ (Fig. 2). Frey earned her medical degree in 1923, with special recognition for her outstanding expertise in neurology, pathology, and anatomy. ${ }^{40}$ She remained in Warsaw until 1928, a date that also marks the end of her short publishing career. She returned to Lwów to work as a neurologist and married Marek Gottesman, the father of her children Jakub and

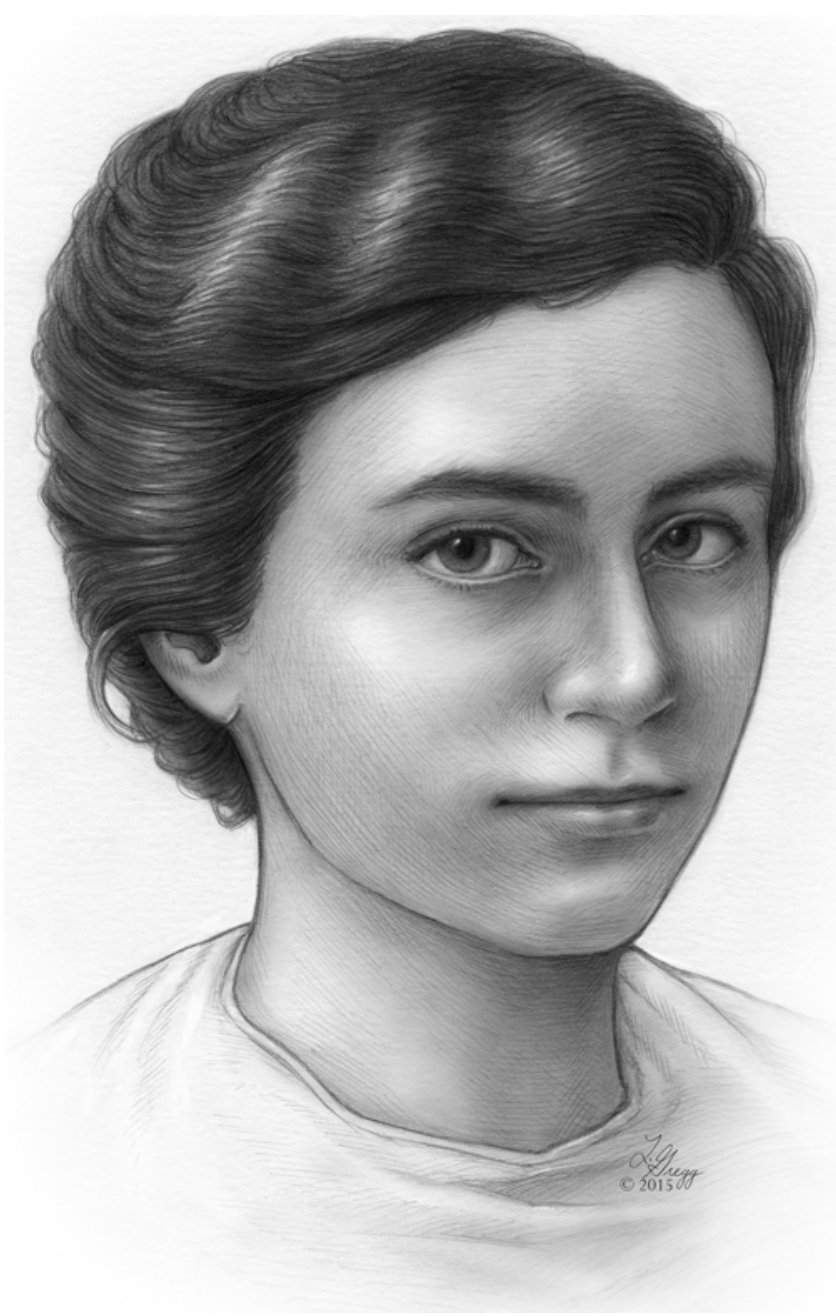

FIG. 2. Portrait of Łucja Frey based on a picture taken while she was working with Professor Orzechowski in Warsaw. @2015 Lydia Gregg.
Danuta. Marek was arrested by Soviet occupation troops in 1940 for obscure reasons and was never seen again. The circumstances of Frey's death in 1942 or 1943 remain unclear as well..$^{39,40}$ The last document proving her alive is a work permit application dated April 1, 1942 (Fig. 3). Łucja Frey was probably murdered on August 20, 1942, with the staff and patients of the Lwów ghetto clinic or was deported around that time to the Belzec death camp. ${ }^{21}$ If she survived longer, her life would have ended with the liquidation of the Lwów ghetto by departing Schutzstaffel units in June 1943.

\section{Frey's Contribution}

Drawing on specialties she was recognized for, i.e., neurology, anatomy, and pathology, Frey described a complex vascular malformation consisting of 2 lesions separated by several segments of unremarkable spinal cord. While not explicitly suggesting a double anomaly, she clearly distinguished 2 types of vascular alterations in her patient: 1) a multiplication (i.e., an increased number) of small or medium-sized vessels, mostly arterial in nature, located within the spinal parenchyma; and 2) a multiplication of hypertrophied pial vessels, occasionally "penetrating" the spinal cord via the anterior fissure. Both types of anomalies were present in the cranial lesion, as expected with a spinal AVM, but only the pial component was found in the caudal one, suggesting a strictly superficial anomaly, likely a perimedullary arteriovenous fistula (AVF) (Fig. 4).

While the caudal lesion could represent a secondary phenomenon, such as the aneurysmal dilation of an arterial feeder or draining vein of the cranially located spinal AVM, Frey's detailed report does not mention a connection between the 2 anomalies, either at the macroscopic or microscopic levels. When she described the morphology of the abnormal perimedullary vessels, Frey noted that a section through the fourth thoracic segment, i.e., in between the 2 lesions, "already showed a normal appearance," while 4 segments lower, "one found again...a large and dilated vessel located along the midline, almost reaching the posterior aspect of the cord." It appears unlikely that Frey would have failed to notice the continuity of the 2 anomalies if they were part of a single entity. The following assessment of her professional qualities by a contemporary physician should comfort us in that opinion: ${ }^{25,40}$

Łucja Frey was extraordinarily modest, quiet and as hard working as an ant. She was distinguished to no mean extent by innovative creativity. All her works were characterized by an exceptional accuracy, a seeking for a wide and versatile understanding of the problem under study as well as a deep knowledge of her subject.

If one accepts that the 2 lesions are separate, Frey's observation represents the rare, possibly unreported combination of a spinal AVM (at C7-T2) with a perimedullary AVF (at T8-10) or, less likely, with an unrelated giant aneurysm of the anterior spinal artery. The final word belongs to Frey herself. While the vascular changes within the cranial lesion mostly involved arteries, she noted that the enlarged vessel without a detectable elastic layer constituting the lower lesion was likely a vein. Aneurysms associated with perimedullary AVFs are typically enlarged 


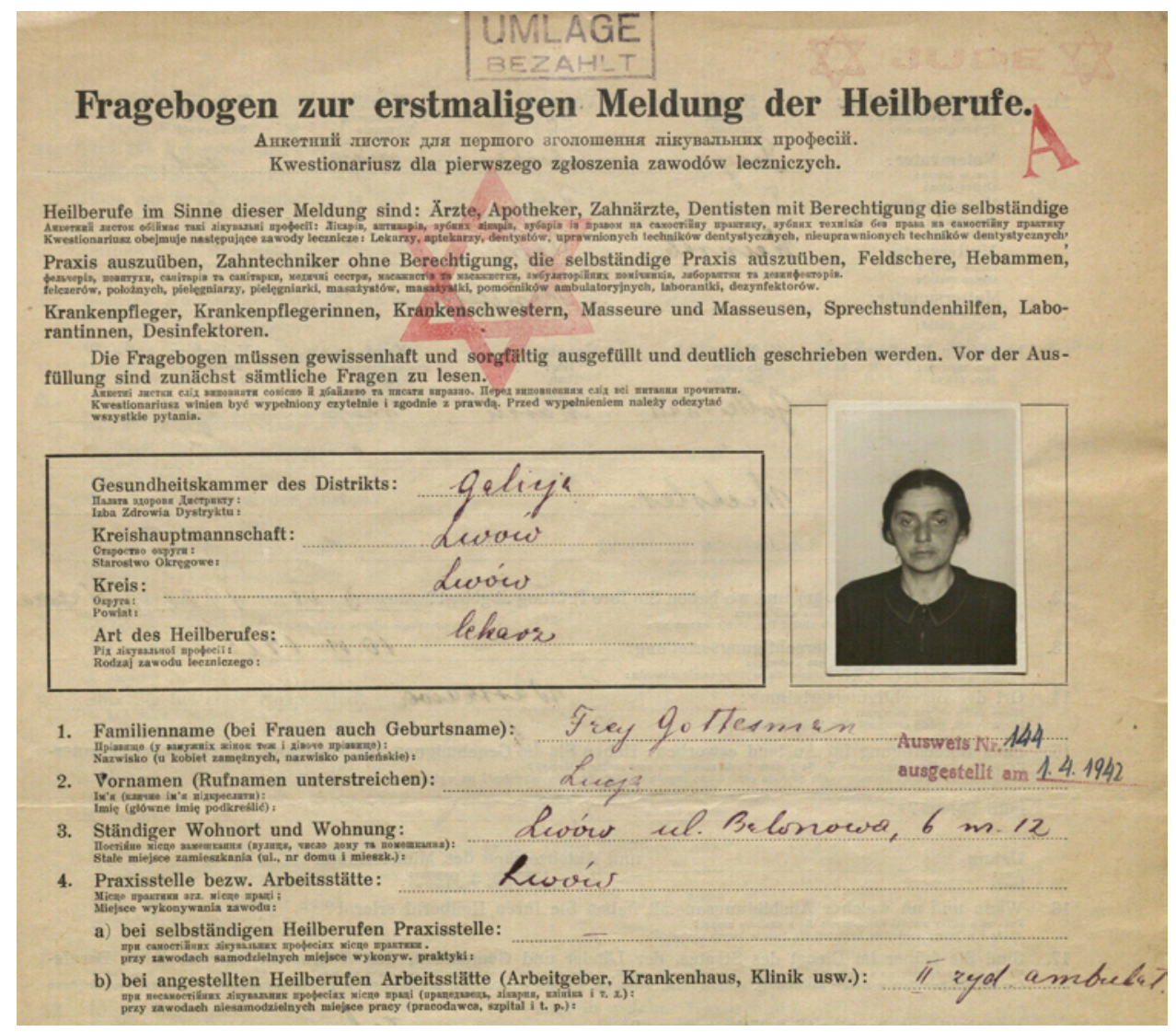

FIG. 3. Reproduction of a permit dated April 1, 1942, authorizing Łucja Frey to work as a physician in the Lwów ghetto. This document is now conserved at the United States Holocaust Memorial Museum in Washington, DC (Record Group 2002.34, "Lucja Frey Gottesman collection"). Public domain. Figure is available in color online only.

veins found on the venous side of the arteriovenous shunt. Frey's description of the caudal anomaly leaves little doubt in regard to its nature: a large venous aneurysm within the anterior-median fissure, responsible for extensive cord deformation, and compression without actual parenchymal invasion, strongly suggesting the diagnosis of a perimedullary AVF. In fact, Frey's illustrations offer strikingly accurate depictions of the typical appearance of spinal AVMs (Fig. 1A) and perimedullary AVFs (Fig. 1B).

Frey's discussion demonstrates the difficulty of recognizing and classifying spinal vascular anomalies before the introduction of spinal angiography in the 1960s..$^{9,10}$ The lesions described by Gaupp,$^{18}$ Lindenmann, ${ }^{32}$ and Sargent, ${ }^{54}$ considered by Frey as unrelated to her observation, are all perimedullary AVFs and are essentially identical to the caudal lesion of her patient. Interestingly, Sargent himself separated his fifth case, described as an "arterial angioma," from the other 4 , which he characterized as "venous angiomas," based on the presence of an aneurysmal component compressing the spinal cord.

Frey rightfully considered Raymond and Cestan's observation to be similar to hers..$^{48}$ In fact, these authors likely reported the first documented case of spinal AVM. Having noted the "participation of diverse vascular elements, veins, capillaries, arteries," they ruled out "simple spinal varices" and suggested instead the diagnosis of cirsoid aneurysm, emphasizing the presence of both intra- and extramedullary abnormal vessels. However, Frey's observation and illustrations offer a much better representation of the lesion, allowing unambiguous identification of her case as a spinal AVM: an intraaxial mass made of "vessels of various sizes," i.e., our current "nidus," associated with enlarged perimedullary arteries and veins. The second report Frey believed to be comparable to hers, published by Meyer and Kohler in 1917,38 was either a spinal AVM or a perimedullary AVF. A definitive identification remains impossible as the fatal hemorrhage suffered by the patient resulted in extensive tissue disruption.

To our knowledge, the only excellent anatomopathological description of a spinal AVM predating Frey's is the one offered by Pelz in 1917 of a 22-year-old man, who presented with a 1-year history of back and leg pain, progressive paraparesis, and bladder incontinence, and died a few hours after an inconclusive surgical exploration..$^{45}$ The autopsy showed the lumbosacral perimedullary veins "bulging with blood, enlarged, and very tortuous." The diagnosis was clarified by the microscopic examination, which revealed "the multiplication and hypertrophy of intra- and extramedullary vessels." Pelz's contribution remains generally unappreciated. The title and focus of his article ("Casuistic contribution to the study of spinal cord neoplasms") may explain why this important work is neither mentioned in Frey's bibliography nor in most modern reviews on the topic. ${ }^{1,3,62}$ 


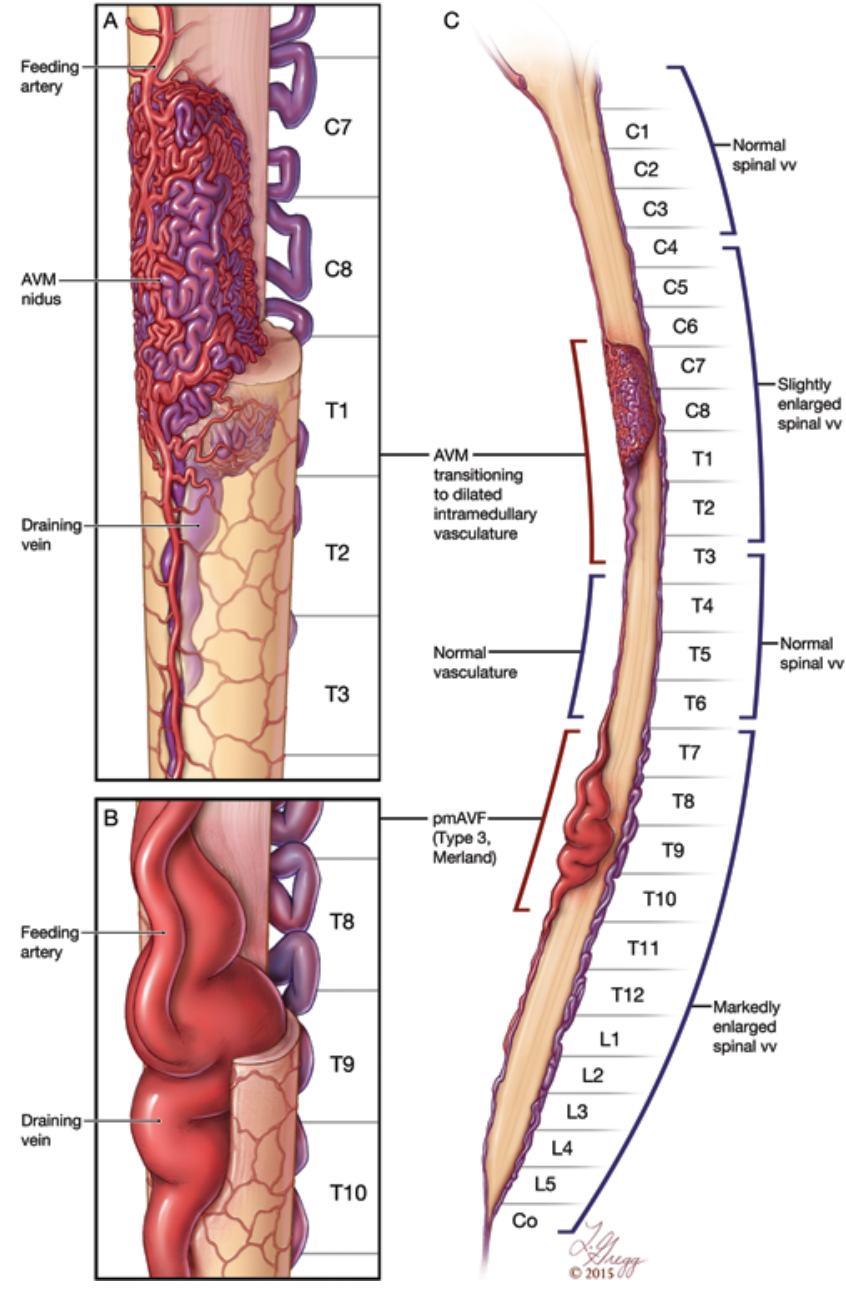

FIG. 4. Artistic representation of Frey's observation based on her publication, showing a spinal AVM at C7-T2, and a perimedullary AVF at T8-10, with an intermediate segment of normal spinal cord and spinal vessels from T-4 to T-7. pm = perimedullary; vv = veins. C2015 Lydia Gregg. Figure is available in color online only.

\section{Multiple Spinal Vascular Malformations in the Literature}

Distinguishing synchronous and metachronous vascular malformations is conceptually simple. In practice, however, the words "synchronous" and "metachronous" generally imply a diagnostic time frame rather than a pathological one. Two lesions may appear metachronous only because one was initially overlooked, for example, when initial angiography was incomplete or misinterpreted..$^{26,31,58}$ Alternatively, a second anomaly may only become angiographically detectable after treatment of the first lesion. ${ }^{41}$ On the other hand, the simultaneous diagnosis of 2 vascular malformations does not exclude a causative relationship. ${ }^{30}$ The hemodynamic alterations induced by a vascular malformation may result in the formation of other lesions, notably through the development of venous hypertension and/or thrombosis. ${ }^{46,49}$ Finally, a secondary vascular malformation may develop as an iatrogenic response to the treatment of the initial lesion. ${ }^{14,49}$ To remain consistent with the literature, multiple lesions were cat- egorized here as synchronous if diagnosed simultaneously and metachronous otherwise.

Twenty-three well-documented cases of multiple spinal vascular malformations are listed in Table 1 . Lesions that appeared upon review to be solitary, ${ }^{42,43,50,51}$ single malformations with multifocal shunts, ${ }^{5}$ and lesions with insufficient or absent angiographic documentation ${ }^{35-37,57}$ were excluded. Merland and colleagues offered the earliest mention of multiple spinal dural AVFs (DAVFs) (4 of 56 cases) in 1986, without specific details or angiographic images. ${ }^{37}$ Pierot and colleagues published the first 2 angiographic observations of multiple spinal DAVFs in $1993 .{ }^{46}$ Most cases of synchronous or metachronous multiple spinal vascular malformations published since then involve spinal DA VFs. $2,7,11,19,31,49,56,58,60,61$ A few observations combine spinal DAVFs with perimedullary AVFs ${ }^{8,26,29,33,41,44}$ (including 2 perimedullary AVFs labeled as spinal AVMs ${ }^{26,44}$, while a small number of cases involves only fast-flow lesions (spinal AVMs and/or perimedullary AVFs). ${ }^{35,47,59}$

The review of older material is challenging. Spinal DAVFs and spinal epidural arteriovenous fistulas were not clearly distinguished until recently, a fact likely explaining the absence of the latter type of malformation in the current review. Likewise, the "spinal AVM" label is often used to describe perimedullary AVFs as well as "true" spinal AVMs. We have therefore chosen to subcategorize the well-documented cases of multiple spinal vascular malformations into "acquired" (spinal DAVF/spinal epidural AVF) or "congenital" (spinal AVM/perimedullary AVF) lesions $^{53}$ (with the exception of the 2 reports combining spinal AVMs with atypical intradural nerve root arteriovenous malformations without dural involvement ${ }^{35}$ ). In 12 of these 21 cases (57\%), both lesions were of the acquired type. In 6 instances (29\%), one was acquired and the other was congenital. Finally, in only 3 cases (14\%) were both anomalies of the congenital type. When considering the age of presentation, it is worth noting that patients with multiple "acquired" lesions were on average 55.8 years old (median 61.5 years, range 24-72 years), and likely developed multifocal anomalies in a time frame consistent with the reported natural history of slow-flow arteriovenous fistulas ${ }^{53}$ On the other hand, the average age of patients combining "acquired" and "congenital" lesions was only 36.5 years (median 39.5 years, range $14-61$ years). It is therefore possible that the formation of an acquired lesion was accelerated in the latter group by the presence of a congenital anomaly, for example, through the development of spinal venous hypertension or thrombosis. ${ }^{46,49}$ This hypothesis is further strengthened by the fact that at least one lesion was of the acquired type in $86 \%$ of the well-documented cases of multiple vascular malformations, a dominance suggesting a causative relationship and a metachronous time frame in most instances.

\section{Conclusions}

Three cases of spinal AVMs were published prior to Frey's report. Pelz ${ }^{45}$ provided the first unambiguous description in 1917, but his contribution remains widely unappreciated to this day. The other 2 reports by Raymond and Cestan $^{48}$ and by Meyer and Kohler ${ }^{38}$ were less 
TABLE 1. Literature review on multiple spinal vascular malformations

\begin{tabular}{|c|c|c|c|c|c|c|c|c|}
\hline \multirow[b]{2}{*}{ Authors \& Year } & \multirow{2}{*}{$\begin{array}{c}\text { Age (yrs) } \\
\text { Sex }\end{array}$} & \multirow[b]{2}{*}{ Timing } & \multicolumn{2}{|c|}{ Lesion 1} & \multicolumn{2}{|c|}{ Lesion 2} & \multicolumn{2}{|r|}{ Lesion 3} \\
\hline & & & Type & Location* & Type & Location* & Type & Location* \\
\hline Frey, 1928 & $52, \mathrm{M}$ & Synchronous & SAVM & Cervicothoracic & PmAVF & Thoracic & & \\
\hline Thiebot et al., 1986 & $24, F$ & Synchronous & SDAVF & Thoracic & SDAVF & Thoracic & SDAVF & Lumbar \\
\hline Tan et al., 1990 & $19, \mathrm{M}$ & Synchronous & SAVM & Cervical & SAVM & Thoracic & & \\
\hline Barnwell et al., 1991 & $69, \mathrm{~F}$ & Metachronous? & SDAVF & Cervical & SDAVF & Cervical & & \\
\hline \multirow[t]{2}{*}{ Pierot et al., 1993} & $47, \mathrm{M}$ & Synchronous & SDAVF & Thoracic & SDAVF & Thoracic & & \\
\hline & $64, \mathrm{M}$ & Synchronous & SDAVF & Thoracic & SDAVF & Thoracic & & \\
\hline Chaloupka et al., 1995 & $48, M$ & Synchronous & SDAVF & Lumbar & SDAVF & Thoracic & & \\
\hline \multirow[t]{2}{*}{ Matsumaru et al., 1999} & $34, \mathrm{M}$ & Synchronous & SAVM & Cervical & RAVM & Cervical & & \\
\hline & $32, \mathrm{~F}$ & Synchronous & SAVM & Lumbar? & RAVM & Lumbar & & \\
\hline Piske et al., 2001 & $5, \mathrm{M}$ & Synchronous & PmAVF & Thoracolumbar & PmAVF & Thoracolumbar & PmAVF & Thoracolumbar \\
\hline Dam-Hieu et al., 2001 & $49, \mathrm{M}$ & Synchronous & PmAVF & Lumbar & SDAVF & Thoracic & & \\
\hline Hsu et al., 2002 & $44, \mathrm{M}$ & Metachronous & SAVM (PmAVF) & Lumbosacral & SDAVF & Sacral & & \\
\hline van Dijk et al., 2002 & $62, \mathrm{M}$ & Metachronous & SDAVF & Thoracic & SDAVF & Thoracic & & \\
\hline Nishio et al., 2003 & $16, F$ & Synchronous & SAVM (PmAVF) & Lumbosacral & SDAVF & Lumbar & & \\
\hline Krings et al., 2004 & $63, \mathrm{M}$ & Synchronous & SDAVF & Lumbar & SDVAF & Lumbar & & \\
\hline Morgalla et al., 2004 & $61, \mathrm{M}$ & Metachronous & SDAVF & Thoracic & PmAVF & Thoracic & & \\
\hline Ling et al., 2005 & $14, \mathrm{M}$ & Metachronous & PmAVF & Thoracic & SDAVF & Thoracic & & \\
\hline Sugawara et al., 2005 & $72, \mathrm{M}$ & Metachronous & SDAVF & Thoracic & SDAVF & Lumbar & & \\
\hline Krings et al., $2006^{29}$ & $35, M$ & Synchronous & PmAVF & Thoracic & SDAVF & Thoracic & & \\
\hline El-Serwi et al., 2006 & $47, M$ & Synchronous & SDAVF & Thoracic & SDAVF & Thoracic & & \\
\hline Rizvi et al., 2006 & $50, M$ & Metachronous & SDAVF & Thoracic & SDAVF & Lumbar & & \\
\hline Shankar et al., 2011 & $61, M$ & Synchronous & SDAVF & Cervical & SDAVF & Cervical & SDAVF & Cervical \\
\hline Ge et al., 2013 & $62, \mathrm{M}$ & Synchronous & SDAVF & Thoracic & SDAVF & Thoracic & & \\
\hline
\end{tabular}

PmAVF = perimedullary AVF; SDAVF = spinal DAVF; RAVM = radicular AVM; SAVM = spinal AVM.

* The spinal cord level involved by the lesion for spinal AVMs and perimedullary AVFs, and the level of origin of the feeding artery for spinal DAVFs. In 2 instances in which perimedullary AVFs were originally labeled as spinal AVMs, both diagnoses are indicated.

detailed, leaving room for interpretation in regard to the exact nature of the observed lesions. Thus, in spite of its later publication date, Frey's detailed and unequivocal description substantiates the claim that her work constitutes a landmark contribution to the modern understanding of spinal AVMs.

More importantly, Frey's observation includes a second, separate spinal vascular anomaly that shows the typical anatomopathological features of a perimedullary AVF. While her paper offers enough elements establishing the absence of connections between the 2 anomalies, Frey stopped short of suggesting double vascular malformations, whose existence would only be recognized decades later, after the introduction of spinal angiography. It is our opinion, however, that Łucja Frey offered the first observation of a synchronous double spinal vascular malformation and, to this day, the only one associating a spinal AVM with a perimedullary AVF.

\section{References}

1. Akopov SE, Schievink WI: History of spinal cord vascular malformations and their treatment. Semin Cerebrovasc Dis Stroke 2:178-185, 2002

2. Barnwell SL, Halbach VV, Dowd CF, Higashida RT, Hieshi- ma GB, Wilson CB: Multiple dural arteriovenous fistulas of the cranium and spine. AJNR Am J Neuroradiol 12:441445, 1991

3. Barrow DL, Johnson WD: Historical perspective and classification of spinal vascular malformations, in Barrow DL, Awad IA (eds): Spinal Vascular Malformations. Park Ridge, IL: The American Association of Neurological Surgeons, 1999, pp 1-7

4. Berenbruch K: Ein Fall von multiplen Angiolipomen, kombiniert mit einem Angiom des Rückenmarks [dissertation]. University of Tübingen, 1890

5. Brasch F: Ueber einen schweren spinalen Symptomencomplex bedingt durch eine aneurysma-serpentinumartige Veränderung eines Theils der Rückenmarksgefässe. Berliner Klin Wochenschr 37:1210-1213, 1239-1241, 1900

6. Burton MJ, Brochwicz-Lewinski M: Lucja Frey and the auriculotemporal nerve syndrome. J R Soc Med 84:619-620, 1991

7. Chaloupka JC, Gobin YP, Guglielmi G, Steichen JD, Vinuela F: Two concurrent spinal dural arteriovenous fistulae in a patient with rapidly progressive myelopathy. A case report. Angiology 46:251-257, 1995

8. Dam-Hieu P, Mineo JF, Bostan A, Nonent M, Besson G: Concurrent spinal dural and intradural arteriovenous fistulas. Case report. J Neurosurg 95 (1 Suppl):96-99, 2001

9. Di Chiro G, Doppman J, Ommaya AK: Selective arteriography of arteriovenous aneurysms of spinal cord. Radiology 88:1065-1077, 1967 
10. Djindjian R, Houdart R, Hurth M: Acquisitions récentes en angiographie médullaire. Rev Neurol (Paris) 115:10681069,1966

11. El-Serwi A, Maubon A, Vidal J, Chapot R: Double spinal dural arteriovenous fistulas. AJNR Am J Neuroradiol 27:321-323, 2006

12. Elsberg CA: Diagnosis and Treatment of Surgical Diseases of the Spinal Cord and its Membranes. Philadelphia: W.B. Saunders Company, 1916

13. Emeryk-Szajewska B, Kwieciński H: Professor Kazimierz Orzechowski-initiator of the first university department of neurology in Warsaw. Neurol Neurochir Pol 45:188-194, 2011

14. Flannery T, Tan MH, Flynn P, Choudhari KA: Delayed postsurgical development of dural arteriovenous fistula after cervical meningocele repair. Neurol India 51:390-391, 2003

15. Frazier CH, Russell EC: Télangiectasie de la moelle. Arch franco-belges chir 28:140-145, 1925

16. Frey $Ł$ : Etude anatomo-clinique d'un cas d'anévrisme cirsoide de la moelle épinière. Ann Anat Pathol (Paris) 5:971979, 1928

17. Frey Ł: Przypadek tętniaka splotowatego rdzenia. Neurologia Polska 9:21-30, 1926

18. Gaupp J: Casuistische Beiträge zur pathologischen Anatomie des Rückenmarks und seiner Häute. Beiträge pathol Anat Physiol 2:510-524, 1888

19. Ge L, Feng R, Zhang X, Sun B, Gu S, Xu Q, et al: Multidisciplinary management of multiple spinal dural arteriovenous fistulae. Int J Clin Exp Med 6:814-821, 2013

20. Glaser G: Ein Fall von centralem Angiosarkom des Rückenmarks. Arch Psychiatr Nervenkr 16:87-100, 1885

21. Grzybowski A, Sak J: Lucja Frey (1889-1942): life destroyed by the Holocaust-on the 70th anniversary of her death. Clin Dermatol 30:355-359, 2012

22. Guillain G, Alajouanine T: Paraplégie par compression due à un volumineux angiocele de la pie-mère spinale. Contribution à I'étude des compressions médullaires dues à des formations vasculaires pathologiques. J Neurol Psychiatry 11:689-697, 1925

23. Hadlich R: Ein Fall von Tumor cavernosus des Rückenmarks mit besonderer Berücksichtigung der neueren Theorien über die Genese des Cavernoms. Virchows Arch 172:429-445, 1903

24. Hebold O: Aneurysmen der kleinsten Rückenmarksgefässe. Arch Psychiatr Nervenkr 16:813-823, 1885

25. Herman E: Wspomnienia posmiertne. Neurol Pol 24:27-28, 1950

26. Hsu SW, Rodesch G, Luo CB, Chen YL, Alvarez H, Lasjaunias PL: Concomitant conus medullaris arteriovenous malformation and sacral dural arteriovenous fistula of the filum terminale. Interv Neuroradiol 8:47-53, 2002

27. Jumentié J, Levy-Valensi J: Dilatations variqueuses des veines spinales postérieures. Rev Neurol (Paris) 22:81-83, 1911

28. Krause F: Chirurgie des Gehirns und Rückenmarks nach eigenen Erfahrungen. II. Band. Berlin: Urban \& Schwarzenberg, 1911

29. Krings T, Coenen VA, Weinzierl M, Reinges MH, Mull M, Thron A, et al: Spinal dural arteriovenous fistula associated with a spinal perimedullary fistula: case report. J Neurosurg Spine 4:241-245, 2006

30. Krings T, Mull M, Bostroem A, Otto J, Hans FJ, Thron A: Spinal epidural arteriovenous fistula with perimedullary drainage. Case report and pathomechanical considerations. J Neurosurg Spine 5:353-358, 2006

31. Krings T, Mull M, Reinges MH, Thron A: Double spinal dural arteriovenous fistulas: case report and review of the literature. Neuroradiology 46:238-242, 2004

32. Lindenmann A: Varicenbildung der Gefässe der Pia mater spinalis und des Rückenmarks als Ursache einer totalen Querschnittsläsion. Z Gesamte Neurol Psychiatr 12:522529,1912

33. Ling JC, Agid R, Nakano S, Souza MP, Reintamm G, Terbrugge KG: Metachronous multiplicity of spinal cord arteriovenous fistula and spinal dural AVF in a patient with hereditary haemorrhagic telangiectasia. Interv Neuroradiol 11:79-82, 2005

34. Lorenz O: Kavernöses Angiom des Rückenmarks [dissertation]. Jena, Germany: University of Jena, 1901

35. Matsumaru Y, Pongpech S, Laothamas J, Alvarez H, Rodesch G, Lasjaunias P: Multifocal and metameric spinal cord arteriovenous malformations. Review of 19 cases. Interv Neuroradiol 5:27-34, 1999

36. Meisel HJ, Lasjaunias P, Brock M: Multiple arteriovenous malformations of the spinal cord in an adolescent: case report. Neuroradiology 38:490-493, 1996

37. Merland J, Assouline E, Rüfenacht D, Guimaraens L, Laurent A: Dural spinal arteriovenous fistulae draining into medullary veins. Clinical and radiological results of treatment (emboliation and surgery) in 56 cases, in Valk J (ed): Neuroradiology 1985/1986: Proceedings of the XIIIth Congress of the European Society of Radiology. Amsterdam: Excerpta Medica, 1986

38. Meyer O, Kohler B: Über eine auf kongenitaler Basis entstandene kavernomähnliche Bildung des Rückenmarks. Frankf Z Pathol 20:37-56, 1917

39. Moltrecht M: Dr. med. Łucja Frey: eine Ärztin aus Lwów, 1889-1942. Rekonstruktion eines Lebens. Konstanz, Germany: Hartung-Gorre, 2004

40. Moltrecht M, Michel O: The woman behind Frey's syndrome: the tragic life of Lucja Frey. Laryngoscope 114:2205-2209, 2004

41. Morgalla MH, Ernemann U, Gawlowski J, Deininger M, Bitzer M, Grote EH: Recurrent spinal fistula as result of a rare combination of a perimedullary and peridural spinal fistula: case report. Surg Neurol 61:347-352, 2004

42. Nakstad PH, Hald JK, Bakke SJ: Multiple spinal arteriovenous fistulas in Klippel-Trenaunay-Weber syndrome treated with platinum fibre coils. Neuroradiology 35:163-165, 1993

43. Niimi Y, Ito U, Tone O, Yoshida K, Sato S, Berenstein A: Multiple spinal perimedullary arteriovenous fistulae associated with the Parkes-Weber syndrome. A case report. Interv Neuroradiol 4:151-157, 1998

44. Nishio A, Ohata K, Takami T, Gotoh T, Tsuyuguchi N, Ichinose T, et al: Spinal arteriovenous malformation associated with a radicular arteriovenous fistula suggested a metameric disease. A case report. Interv Neuroradiol 9:75-78, 2003

45. Pelz A: Kasuistische Beiträge zur Lehre von den Rückenmarksgeschwülsten. Arch Psychiatr Nervenkr 58:195-215, 1917

46. Pierot L, Vlachopoulos T, Attal N, Martin N, Bert S, Chiras J: Double spinal dural arteriovenous fistulas: report of two cases. AJNR Am J Neuroradiol 14:1109-1112, 1993

47. Piske R, Sampaio M, Campos C, Nunes JA Jr, Lima SS: Trifocal monomyelomeric spinal cord arteriovenous fistulae in a seven-year-old boy. Interv Neuroradiol 7:121-126, 2001

48. Raymond F, Cestan R: Un cas d'anévrisme cirsoide probable de la moelle cervicale. Rev Neurol (Paris) 12:457-463, 1904

49. Rizvi T, Garg A, Mishra NK, Gaikwad SB, Gupta V: Metachronous double spinal dural arteriovenous fistulas. Case report and review of the literature. J Neurosurg Spine 4:503-505, 2006

50. Rodesch G, Lasjaunias P: Multiple arteriovenous fistulae in the Klippel-Trenaunay-Weber syndrome (KTW). Neuroradiology 35:561-562, 1993

51. Rohany M, Shaibani A, Arafat O, Walker MT, Russell EJ, Batjer HH, et al: Spinal arteriovenous malformations associated with Klippel-Trenaunay-Weber syndrome: a literature 
search and report of two cases. AJNR Am J Neuroradiol 28:584-589, 2007

52. Roman B: Ein Fall von Hämangiom des Rückenmarks. Centrabl Allgemeine Pathologie Pathol Anat 23:993-997, 1913

53. Rosenblum B, Oldfield EH, Doppman JL, Di Chiro G: Spinal arteriovenous malformations: a comparison of dural arteriovenous fistulas and intradural AVM's in 81 patients. J Neurosurg 67:795-802, 1987

54. Sargent P: Haemangeioma of the pia mater causing compression paraplegia. Brain 48:259-278, 1925

55. Schneider P: Über ein Lymphangiom am Rückenmark, mit Bemerkungen über sekundäre Degeneration, in Schwalbe E (ed): Festschrift für Professor Julius Arnold. Siebentes Supplement der Beiträge zur pathologischen Anatomie und zur allgemeinen Pathologie. Jena, Germany: Gustav Fischer, 1905, pp 597-617

56. Shankar JJ, terBrugge K, Krings T: Multiple spinal and cranial dural arteriovenous fistulas. J Neurosurg Spine 15:113116,2011

57. Sharma S: Multifocal intradural spinal AVF and renal artery aneurysms in a case of Klippel Trenaunay Syndrome (KTS). J Neuroimaging 20:386-389, 2010

58. Sugawara T, Kinouchi H, Itoh Y, Mizoi K: Multiple spinal dural arteriovenous fistulas. Acta Neurochir (Wien) 147:423-426, 2005
59. Tan EC, Takagi T, Nagai H: [Spinal arteriovenous malformations in Klippel-Trénaunay-Weber syndrome: case report.] No Shinkei Geka 18:877-881, 1990 (Jpn)

60. Thiebot J, Clavier E, Tadie M, Freger P, Dandelot J, Benozio M: Multiple intrathecal extramedullary arteriovenous fistulae draining "freely" into the spinal veins. J Neuroradiol 13:173-180, 1986

61. van Dijk JM, terBrugge KG, Willinsky RA, Wallace MC: Multiplicity of dural arteriovenous fistulas. J Neurosurg 96:76-78, 2002

62. Wyburn-Mason R: The Vascular Abnormalities and Tumours of the Spinal Cord and its Membranes. London: Henry Kimpton, 1943

\section{Disclosures}

The author reports no conflict of interest concerning the materials or methods used in this study or the findings specified in this paper.

\section{Correspondence}

Philippe Gailloud, Division of Interventional Neuroradiology, The Johns Hopkins Hospital, Bloomberg 7218, 1800 E. Orleans St., Baltimore, MD 21287. email: phg@jhmi.edu. 